\title{
Inter- and Intra-specific variation in egg size among reef fishes across the Isthmus of Panama
}

\section{Ross Robertson ${ }^{* \dagger}$ and Rachel Collin ${ }^{\dagger}$}

Smithsonian Tropical Research Institute, Balboa, Panama

\section{Edited by:}

Michael Arthur St. John, Technical University of Denmark, Denmark

\section{Reviewed by:}

Mariano González-Castro, Consejo

Nacional de Investigaciones

Cientificas y Técnicas, Argentina

Ian A. E. Butts, Technical University of Denmark, Denmark

\section{${ }^{*}$ Correspondence:}

D. Ross Robertson, Smithsonian Tropical Research Institute, Unit 9100, Box 0948, DPO, AA 34002, USA

e-mail:drr@stri.org

${ }^{t}$ These authors have contributed equally to this work.

\begin{abstract}
Effects of planktonic food supplies and temperature on pelagic fish larvae are thought to be the primary environmental determinants of adaptive variation in egg size. Differences between the Atlantic and Pacific coasts of Panama in primary production (higher in the Pacific due to upwelling) and temperature (less seasonal in the non-upwelling Caribbean) allow testing such ideas. We compared the volumes, dry weights, and energy content of eggs of 24 species of reef fishes from the two sides of the isthmus during the cool and warm seasons. Both egg volume and egg dry weight were good predictors of egg energy content among species, although not within species. Caribbean species produced larger eggs than their close relatives in the Pacific. In the Pacific, eggs were significantly larger during the cool upwelling season than during the warm, non-upwelling period, with a similar but weaker seasonal pattern evident in the Caribbean. The production of larger eggs in the low-productivity Caribbean is consistent with the hypothesis that species produce larger eggs and offspring when larval food supplies are lower. Parallel patterns of seasonal variation in eggs size and the greater strength of that relationship in the Pacific indicate that temperature drives seasonal variation in egg size within species. The decline in egg size with increasing temperature, a general pattern among ectotherms, may be a physiological side-effect, due to differing effects of temperature on various metabolic processes during oogenesis or on hormones that influence growth and reproduction. Alternatively, the seasonal pattern may be adaptive in these fishes, by affecting larval performance or maintaining a particular timeline of major events during embryonic development.
\end{abstract}

Keywords: primary productivity, upwelling, tropical reef-fish, egg-size variation, temperature-size rule, life history evolution, Isthmus of Panama

\section{INTRODUCTION}

Egg-size is a fundamental life history attribute of marine fishes and invertebrates (Bernardo, 1996; Chambers, 1997; Moran and McAlister, 2009; Collin, 2012). Egg size effects the size, growth rate, and survival of hatchling larvae, and, consequently, has cascading effects on offspring fitness (Allen and Marshall, 2014). A major line of inquiry in evolutionary ecology is to understand intra- and inter-specific variation in maternal investment in egg size and offspring size as they relate to environmental conditions, adaptation, physiological constraints and evolutionary history (e.g., Bagenal, 1971; Thresher, 1982; Bernardo, 1996; Chambers, 1997). Large comparative datasets that are needed to detect general patterns are rare among tropical species of the type we consider here.

On a global scale, interspecific comparisons of egg-size in marine fishes and invertebrates often show latitudinal patterns (Bagenal, 1971; Collin, 2003; Moran and McAlister, 2009). Fish species from low latitudes mainly have small pelagic eggs that produce smaller hatchlings while most of those from higher latitudes have large demersal eggs and large hatchlings (Leis et al., 2013). Larger eggs and faster larval growth at higher latitudes may be related to shorter growing seasons (e.g., see Brown et al., 1998). A similar pattern is evident in marine invertebrates where species with small eggs and planktotrophic larval development are more common at low latitudes and species with large eggs and nonfeeding or benthic development are more common at high latitudes (Thorson, 1950; Collin, 2003). On a regional scale, egg size in species with planktonic feeding larvae has long been thought to vary with availability of planktonic food to support larval growth (e.g., Lessios, 1990). Under low productivity conditions females are thought to produce bigger eggs that in turn produce larger, better-provisioned, hatchlings that are better equipped to survive when there is less larval food available (Cushing, 1967; Bagenal, 1971). Data from neotropical invertebrates support this pattern. In Panama, geminate pairs of invertebrate species, which were formed when the rising isthmus of Panama split a single species (Jordan, 1908), display differences in egg size that have been attributed to differences in larval food supplies in the two oceans. The Caribbean has lower productivity than the tropical East Pacific, and Caribbean echinoderms, bivalve molluscs and bryozoans have volumetrically larger eggs or offspring than do their eastern Pacific congeners, a pattern consistent with the larval-food hypothesis (Lessios, 1990; Jackson and Herrera, 1999; Marko and Moran, 2002; Moran, 2004). However, the two coasts of Panama differ in a number of other environmental factors (e.g., salinity: Table 1; and see Alory et al., 2012), allowing for the 
Table 1 | Variation in oceanographic conditions on the Caribbean and Pacific coasts of Panama where we collected fish eggs for this study.

\begin{tabular}{|c|c|c|c|c|}
\hline \multirow{2}{*}{$\begin{array}{l}\text { Variable } \\
\text { [Mean value] }\end{array}$} & \multicolumn{2}{|c|}{ Caribbean } & \multicolumn{2}{|c|}{ Pacific } \\
\hline & $\begin{array}{c}\text { Cool } \\
\text { season }\end{array}$ & $\begin{array}{l}\text { Warm } \\
\text { season }\end{array}$ & $\begin{array}{c}\text { Cool } \\
\text { season }\end{array}$ & $\begin{array}{l}\text { Warm } \\
\text { season }\end{array}$ \\
\hline Temperature $\left({ }^{\circ} \mathrm{C}\right)$ & 27.9 & 28.7 & 25.5 & 28.1 \\
\hline (Range) & $(27.1-30.0)$ & $(26.6-30.0)$ & $\left(18.7^{*}-25.5\right)$ & $(24.9-30.2)$ \\
\hline Salinity (ppt) & 34.8 & 34.2 & 32.2 & 29.2 \\
\hline Nitrate/Nitrite $(\mu \mathrm{m})$ & 0.23 & 0.29 & 1.03 & 0.27 \\
\hline Phosphate ( $\mu \mathrm{m})$ & 0.04 & 0.04 & 0.37 & 0.12 \\
\hline $\begin{array}{l}\text { Chlorophyll A } \\
\left(\mathrm{mg} \mathrm{m}^{-3}\right)\end{array}$ & 0.36 & 0.41 & 1.48 & 0.59 \\
\hline $\begin{array}{l}\text { Phytoplankton } \\
\text { (cells } \mathrm{ml}^{-1} \text { ) }\end{array}$ & 60 & 100 & 663 & 166 \\
\hline $\begin{array}{l}\text { Zooplankton }\left(10^{3}\right. \\
\left.\text { sample }^{-1}\right)\end{array}$ & 0.8 & 1.2 & 8.8 & 7.0 \\
\hline
\end{tabular}

After Table 1 of D'Croz and Robertson (1997); note that warm and cool seasons in that paper differ slightly from those here; * falls as low as $14^{\circ} \mathrm{C}$ in some years.

possibility that other biotic or abiotic factors may have played a role in generating this pattern.

Wellington and Robertson (2001) compared egg-size and larval development among closely related pelagic spawning reef fishes on both sides of the isthmus of Panama, and transisthmian patterns of larval development (but not egg-size variation) among demersal spawners. They found that larval growth rates and pelagic larval duration were similar among closely related transisthmian species of both pelagic and benthic spawners. Because larval development is largely dependent on food availability and/or temperature (Houde, 1989; Heath, 1992; Houde and Zastrow, 1993; Chambers, 1997; Rilling and Houde, 1999; Bailey and Heath, 2001; Wilson and Meekan, 2002; Meekan et al., 2003), these transisthmian similarities raise questions about the extent to which food availability is the main determinant of transisthmian variation in egg size (Wellington and Robertson, 2001). In the present study we extend that work by assessing transisthmian and seasonal patterns of variation in egg-size among geminate and other congeneric demersal spawners, and include a broader range of species than were considered in Wellington and Robertson's (2001) study of larval development.

Intraspecific environmental variation in egg size in marine invertebrates and fishes is often linked to both temperature and productivity. The existence of such intraspecific plasticity is particularly useful in explorations of the adaptive significance of egg size because plastic responses to environmental variation are often considered to be adaptive (Padilla and Adolph, 1996; Hughes et al., 2003; see Einum and Fleming, 2002; for fish eggs in particular). In addition, unlike the situation for interspecific comparisons, intraspecific comparisons are not confounded by independent evolutionary histories. Temperate and tropical fishes in marine and freshwater environments commonly exhibit intraspecific latitudinal and seasonal variation in egg size similar to the interspecific patterns (Cushing, 1967; Bagenal, 1971; Marteinsdottir and Able, 1988; Clarke, 1989; Fleming and Gross, 1990; Chambers, 1997; Johnston and Leggett, 2002; Leis and
McCormick, 2002; Kokita, 2003). In fishes that produce pelagic larvae, egg size usually decreases with increasing primary production (a proxy for larval food supply) and with increasing temperature (Cushing, 1967; Bagenal, 1971; Chambers, 1997). In fact, egg size and offspring size vary inversely with temperature across a diverse array of metazoan taxa (Atkinson et al., 2001, e.g., see Fischer et al., 2003), a pattern referred to as the "offspring temperature-size rule (OTSR)."

Here, we test the productivity hypothesis among neotropical reef fishes that have pelagic larvae by comparing not only eggsize among closely related species separated by the Isthmus of Panama, but also seasonal intraspecific variation in egg-size on both sides of the Isthmus. This extends a study of transisthmian patterns of larval growth and development among many of the same species (Wellington and Robertson, 2001). For the present analysis the most important differences in the environments of the two coasts of the Isthmus are as follows (Table 1; Figure 1): (i) The Pacific side of the Isthmus has a higher average level of primary production, a lower average temperature, and greater seasonal and short-term variation in both factors than does the Caribbean side. (ii) While there is a large peak of primary production, during the markedly cooler upwelling season on the Pacific coast, there is no clear seasonal change in primary production on the Atlantic coast, with only sporadic small increases intermittently throughout the year (D'Croz and Robertson, 1997; and see Figure 1, here.). This decoupling of seasonal temperature and productivity regimes presents an opportunity to disentangle effects of those two important factors.

In this paper examine the evolution of intra- and inter-specific variation in egg size of 24 species of tropical marine fishes from four different families, taking advantage of the varying environmental conditions and seasonal effects generated by the Isthmus of Panama. Based on hypothesized relationships between the various environmental factors and egg-size described above we made the following predictions about variation in egg size. If larval-food availability has an overriding influence on interspecific variation in egg size then (i) eggs of Pacific species should be smaller than those of Atlantic geminates and, perhaps, other congeners. Further, if larval food availability has an overriding influence on intraspecific variation in egg size then (ii) egg-size should be minimal during the cool season in Pacific species, and should show little or no seasonal change in Caribbean species. Alternatively, if temperature is of overriding importance, then (iii) Caribbean species should have smaller eggs than Pacific species, at least during the cool season, and (iv) within species, egg size should be inversely related to temperature on both sides of the Isthmus. It is possible that both environmental factors are involved in determining egg size, influencing patterns of variation in different ways and at different levels.

\section{MATERIALS AND METHODS SEA-TEMPERATURE DATA}

Sea-temperature data were collected at $6 \mathrm{~m}$ depth in Pacheca Island $\left(8.65^{\circ} \mathrm{N}, 79.05^{\circ} \mathrm{W}\right)$, in the Bay of Panama, and at $7 \mathrm{~m}$ depth at Punta de San Blas $\left(9.45^{\circ} \mathrm{N}, 78.99^{\circ} \mathrm{W}\right)$, (Figure 2), on the Caribbean coast, by the Smithsonian Tropical Research Institute's Environmental Monitoring Program (see 
Pacific Panama
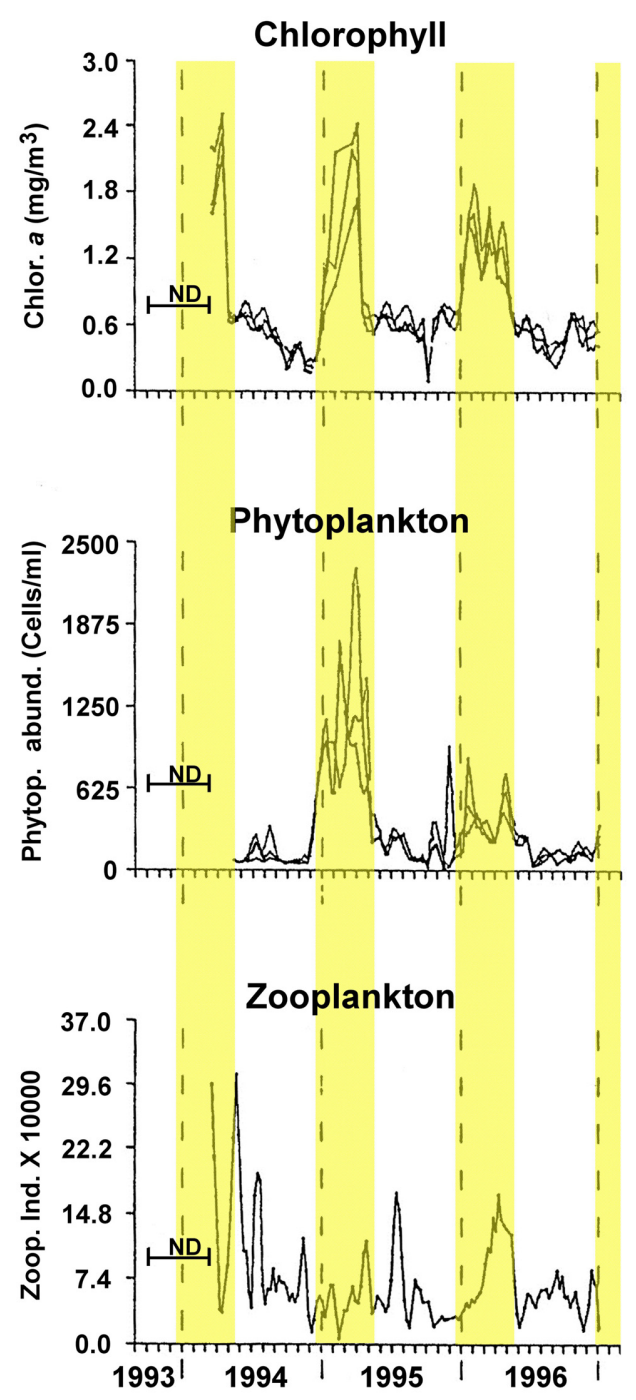

Caribbean Panama

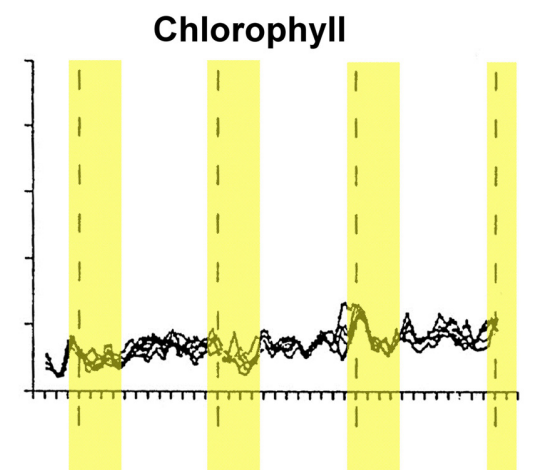

Phytoplankton
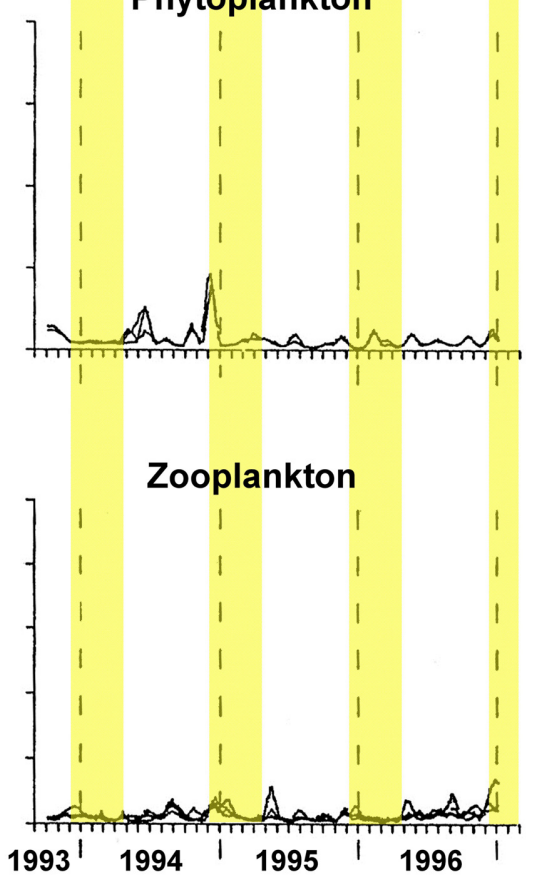

FIGURE 1 | Seasonal changes in chlorophyll, phytoplankton and zooplankton abundance in the Caribbean and Pacific study areas. Redrawn and modified after Figure 5 of D'Croz and Robertson, 1997. Yellow highlighting bands indicate timing of the cool season as used in analyses here.

Kaufman and Thompson, 2005). Hourly or bi-hourly measurements were averaged for each week from 1992 to 2002 for the Pacific, and 1992 to 1999 for the Caribbean, and we used those weekly averages to define the two seasons (Figure 3). For the Caribbean, the cool season included the weeks when average temperature was below $28.5^{\circ} \mathrm{C}$ (weeks $1-15$ and $51-53$ ), with the remainder in the warm season. For the Pacific, cool season included the weeks when the average temperature was below $27^{\circ} \mathrm{C}$ (weeks 1-18 and 52-53).

\section{STUDY SPECIES}

We obtained egg-size data from 24 species representing seven genera and four families of neotropical reef fishes that produce benthic eggs and have pelagic larvae. These include three pairs of transisthmian geminate species: one species pair of Abudefduf and one of Chromis (both Pomacentridae), and one of Ophioblennius (Blenniidae) (see Bermingham et al., 1997; Muss et al., 2001). The single Atlantic and Pacific representatives of Acanthemblemaria belonged to the same clade, but are not geminate sisters (Eytan et al., 2012). The single Pacific species of Coryphopterus is not the geminate sister of any of the three Caribbean species (J Van Tassell, pers. com., 2013). No phylogeny yet exists for Microspathodon, for which we sampled all three neotropical species. Finally, we sampled two of eight east Pacific species and six of seven Caribbean species of Stegastes (Pomacentridae). None of these constitute clearly identifiable geminate sister species pairs, although they belong to four genetic lineages (Rocha et al., unpublished data): lineages I and II include 


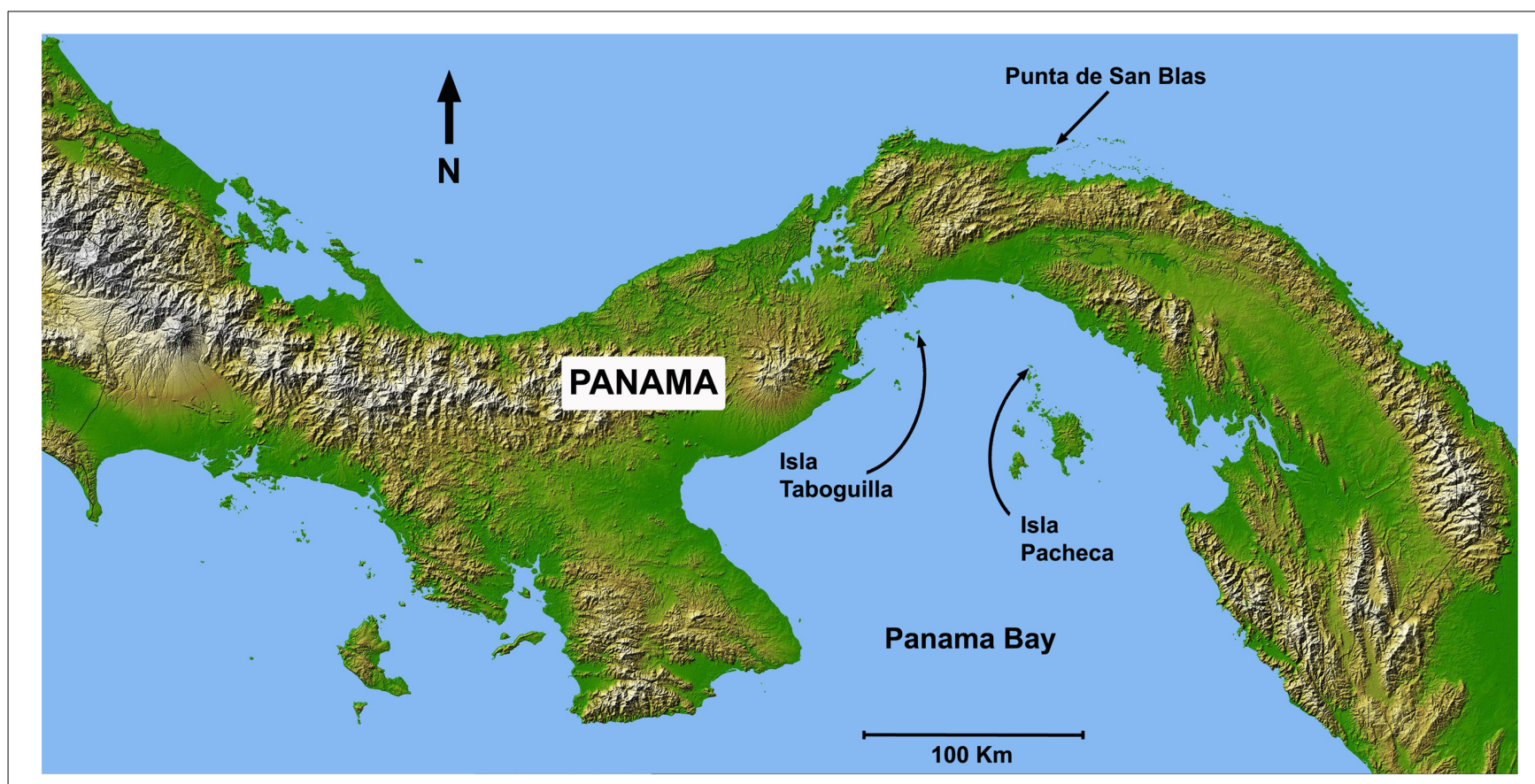

FIGURE 2 | Map of Panama showing Caribbean and Pacific study locations: Taboguilla Island $\left(8.8^{\circ} \mathrm{N}, 79.51^{\circ} \mathrm{W}\right)$, Pacheca $^{\text {Island }}\left(8.65^{\circ} \mathrm{N}, 7^{2} .05^{\circ} \mathrm{W}\right)$, and

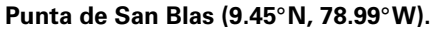

A

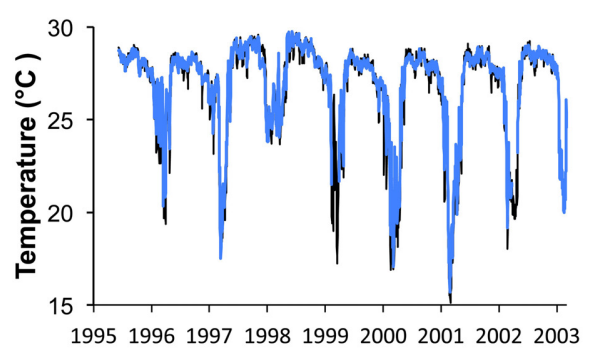

- Taboguilla Pacheca

C

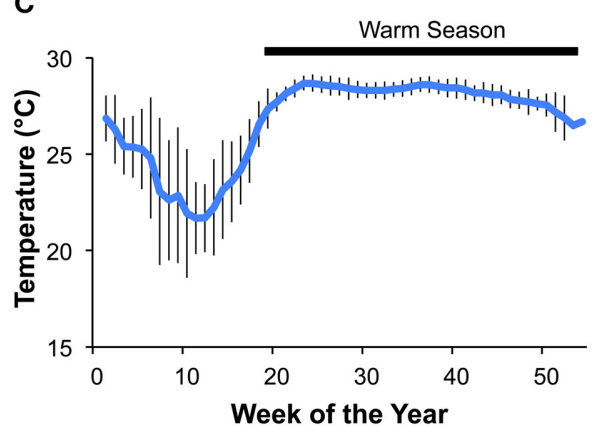

FIGURE 3 | Variation in water temperature at the Caribbean and Pacific study sites. Average daily temperatures for Islas Taboguilla and Pacheca in the Pacific (A) and average daily temperatures for 2 depths at Punta de San Blas (B) show clear seasonal patterns across years. Temperatures averaged across years for the same
B

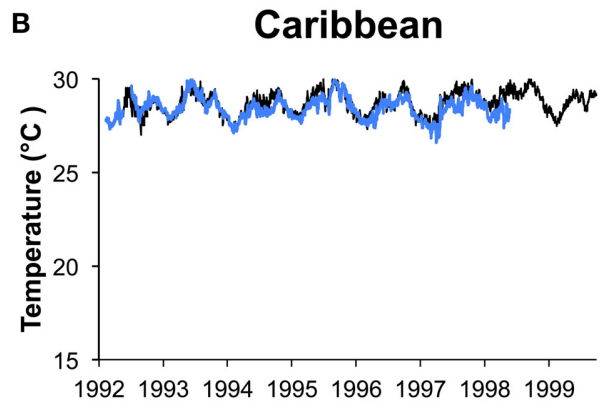

- Shallow $(6 \mathrm{~m}) \quad$ Deep $(21 \mathrm{~m})$

D

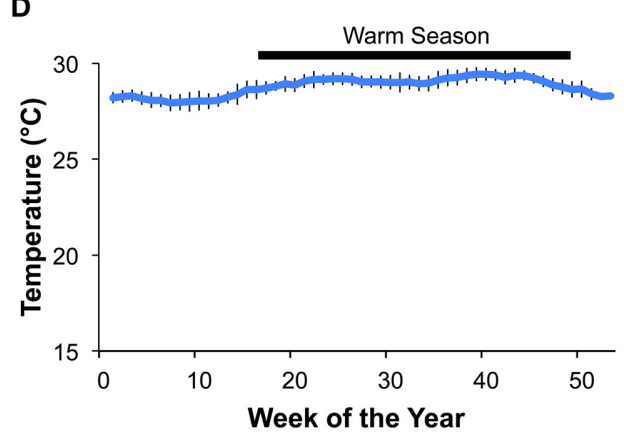

week show a colder and more variable temperatures during upwelling the Pacific depicted with data from Pacheca island (C) compared to the more stable Caribbean depicted with data from the shallow site at Punta de San Blas (D). Vertical lines show standard deviations of the mean. 
S. leucostictus and $S$ partitus respectively, both Caribbean species whose clades lack a Pacific member; lineage III includes S. planifrons (Caribbean) and S. acapulcoensis (Pacific); and lineage IV includes $S$. flavilatus (Pacific), and $S$ adustus, $S$ diencaeus and $S$. variabilis (all Caribbean).

\section{MODES OF REPRODUCTION OF THE STUDY SPECIES}

All the Caribbean species in this study spawn and recruit pelagic larvae throughout the year, although spawning diminishes in many species during the cool season (Robertson, 1990). In the Bay of Panama, the study species spawn throughout most of the year, with a hiatus during the most intense periods of upwelling. Females of all species lay eggs in a close-packed monolayer on a hard nest surface, then leave, and the male cares for the eggs until hatching. Clutches laid on different days occupy different parts of the nest. In some Stegastes species multiple females contribute to a single clutch (e.g., Petersen, 1990) while in others only one female typically does so (e.g., S. leucostictus, Clifton and Robertson, unpublished data). In Abudefduf and Chromis species, each clutch usually is the product of spawning by multiple females, with several often spawning simultaneously in the same nest (Robertson, unpublished observations).

\section{EGG COLLECTION}

In most cases eggs were sampled during lunar peaks of spawning activity (see Robertson, 1990; Robertson et al., 1990), in both warm and cool seasons from 1983 to 1993. However, in four Caribbean species (A. saxatilis, $M$. chrysurus, $S$ diencaeus, and $S$. partitus) $\sim 10$ clutches per month were collected over a 3-year period. Eggs were collected at depths of 1-8 m, at Punta de San Blas (Caribbean coast), and at Taboguilla and Pacheca Islands (Pacific coast; see Figure 2).

Only clutches collected within several hours of being spawned (determined by inspection of newly collected clutches under a dissecting microscope) were used for egg-size assessments. Each sample comprised newly laid eggs collected from a single nest and, in most species, could therefore include eggs from multiple females. To facilitate collection of clean eggs, males of many species were provided with artificial nest substrata: clay tiles, sections of rigid fiberglass sheet, glass jars, and half-sections of PVC tubing. Eggs change color during development and fresh clutches are easy to distinguish from older clutches. Eggs were scraped off the nest surface underwater, sucked into a $20 \mathrm{ml}$ syringe and kept on ice until size measurements were made. Maximum length and maximum width were measured for 20 undamaged eggs in each sample, using a calibrated graduated eyepiece in a Wild M5 dissecting microscope. The sample was then stored frozen until processed for weight and energy content.

In Chromis multilineata naturally spawned eggs invariably had large amounts of sand stuck to them, which precluded accurate measurements of egg-volume in this species. To obtain samples of clean eggs of this species for determination of egg content we speared females in the act of egg-laying, and gently stripped ripe eggs from them into vials within seconds of capture.

\section{ESTIMATION OF EGG VOLUME, WEIGHT, AND ENERGY CONTENT}

Most analyses of egg-size variation in marine fishes have been based on egg diameters or volumes, although egg dry weight and the size of newly hatched larvae have been used in some studies (Chambers, 1997; Kerrigan, 1997; Kokita, 2003; McCormick, 2003). Analyses of transisthmian variation in egg size among invertebrates have been based on either direct measurements of egg diameter or volume (Lessios, 1990; Marko and Moran, 2002), or indirect measurements of offspring size (Jackson and Herrera, 1999; Fortunato, 2004). Although egg volume may accurately predict differences in egg content among species of invertebrates (Jaeckle, 1995; Moran and McAlister, 2009) it does not necessary do so within species (McEdwards and Carson, 1987; McEdwards and Coulter, 1987). In most fishes, the embryo is surrounded in the egg by a large, water-filled perivitelline space (Craik and Harvey, 1984; Riss-Vestergaard, 2002). That space is produced by hydration of the egg, which occurs from shortly before spawning to shortly after fertilization (Tyler and Sumpter, 1996). Variation in the extent of hydration may weaken the relationship between egg volume and content. As all of our study species produce eggs with large perivitelline spaces, variation in egg volume may reflect different levels of hydration rather than maternal investment. Hence we examined egg volume, dry weight and energy content.

\section{DETERMINATION OF AVERAGE EGG VOLUME, DRY WEIGHT, AND ENERGY CONTENT}

We estimated the volumes of the non-spherical (oblate spheroid, ovoid or tapering cylindroid) eggs produced by the study species as follows. Camera lucida drawings were made of the outlines of five eggs from each of two clutches for each species. The sum of the volumes of 150 cylindrical subsections of each of those eggs was used to estimate its total volume. The average of those volumes expressed as the percentage of the volume of a cylinder with the same length and diameter was then calculated. This correction factor was used to estimate the average volume of an egg in each clutch of a species from measurements of maximum length and diameter of 20 eggs per clutch.

For determination of average dry weight and energy content of an egg in a clutch each sample of eggs was first carefully cleaned of all debris under a microscope, then rinsed $\sim 6$ times in distilled water, and finally stored in a $-80^{\circ} \mathrm{C}$ freezer. Subsequently each sample was lyophilized for at least $8 \mathrm{~h}$ and stored in a desiccator in $\mathrm{a}-80^{\circ} \mathrm{C}$. To determine the average dry weight of an egg a subsample of $\sim 20$ counted, intact dried eggs was weighed on a (daily calibrated) Cahn Model 28 Microbalance, after the desiccator containing the samples had been allowed to warm to room temperature in an air-conditioned room. After this the energy density (Joules $\mathrm{mg}^{-1}$ dry weight) of the sample was determined using a Phillipson Microbomb Calorimeter (Gentry Instruments) calibrated with a sample of Benzoic acid at the beginning of each day's measurements. Average energy content of an egg of each clutch was calculated as (average energy density of the clutch) $\times$ (the average dry weight of an egg in that clutch).

\section{STATISTICAL ANALYSES}

The correlation between the average egg volume, dry weight and energy content for each clutch was assessed using Pearson correlations, calculated with $\mathrm{JMP}^{\circledR}$, Version 9.0.2. SAS Institute Inc., Cary, NC, 1989-2007, using the "Multivariate" menu. Due to 
missing values Restricted Maximum Likelihood (REML) was used to calculate the significance of the correlations. For interspecific correlations between different measures of egg size, averages were calculated for warm season egg sizes for each species. Warm season data were used because the temperature conditions experienced then are more typical of the conditions over most of the year, and because the uneven sampling and small cool season sample sizes would unequally effect the species means if they were included. The intraspecific relationship between egg size and temperature was assessed in a similar way. We calculated the correlation between the average egg volume, weight or energy for each clutch with the average temperature recorded for that week.

Incomplete taxon sampling for diverse lineages, and low numbers of species in the fully sampled lineages precluded the use of phylogenetic comparative methods at either the genus- or global levels. Instead we use Two-Way ANOVA's to test for the effects of season and species, and the interaction between season and species on egg size for each genus. Most comparisons included a pair of species, one from the Pacific and one from the Caribbean, although a few involved more species. For Stegastes, the transisthmian comparisons were broken into two clades that each contained one Pacific species: (i) S. acalpulcoensis (Pacific) and planifrons (Caribbean), and (ii) S. flavilatus (Pacific) with, S. adustus, S. diencaeus and S. variabilis (Caribbean). Egg data were $\log$ transformed to reduce inequality among variances before ANOVA tests. Post-hoc Tukey's HSD pairwise comparisons were used to test for significant patterns when significant interactions were present, and power analysis was used to estimate the power of the test and to solve for the least significant number (i.e., the sample size needed for $50 \%$ power, given the raw effect size and the standard error of the residual error in the model) and the least significant value (i.e. the size of an effect that could produce a $p$ value of 0.05 given the sample size and the standard error of the residual error in the model). Because data on egg volume were available for many more dates than the other measures, analyses of egg volume were also conducted on a dataset of clutches for which egg weight data were also available. This was aimed at demonstrating whether any differences between results for egg volume and egg content are due to different sample sizes and/or different distributions of sampling dates.

\section{RESULTS}

\section{RELATIONSHIPS BETWEEN EGG VOLUME AND CONTENT}

Average egg volume, dry weight and energy content varied measurably among clutches from each species. Summary statistics of seasonal means of egg size variation for each species are presented in Supplementary Table 1. Overall, egg volume was not highly correlated with investment per egg within species. The Pearson correlation between average volume of an egg in a clutch and the average dry weight of an egg in the same clutch was statistically significant in only 14 of the 24 species, and volume was significantly correlated with average energy content of eggs for 12 of those 14 species (Table 2). The significant relationships were all positive but the correlation coefficient $(r)$ for the relationship between egg volume and egg weight only exceeded 0.6 for one species, Microspathodon dorsalis, Egg volume was slightly more closely correlated to egg energy content, with $r>0.6$ for four species: M. dorsalis, Chromis atrilobata, Stegastes partitus, and Ophioblennius macclurei. In contrast to egg volume, egg weight was well correlated with egg energy content. The correlations were statistically significant in all species and $r$-values were typically high, with only five species showing an $r<0.9$. The linear relationship between egg volume and the two measures of egg content are given in Supplementary Table 2.

Among species, the average species egg volume was an accurate predictor of both average species egg weight and average egg energy content (Figure 4). Linear regression of species averages from warm season measurements (the season for which the most data were available) show that among species egg volume was a good predictor of egg weight $\left(r^{2}=0.97 ; n=24\right.$; Egg Dry Weight $=0.210$ (volume) -0.001$)$ and of egg energy content $\left(r^{2}=0.975 ; n=22\right.$; Egg Energy $=5.04$ (volume) -0.04). Species from all but one genus, Coryphopterus, fall along the interspecific regression lines for egg volume vs. egg weight and egg energy content (Figure 4). Coryphopterus species fall on the same line as the other species when egg energy content is regressed against egg dry weight (Figures 4E,F).

\section{PATTERNS IN EGG SIZE VARIATION BETWEEN SEASONS AND OCEANS}

In general a Two-Way ANOVA analysis of egg size in each genus showed a pattern of larger egg size in Caribbean species compared to their Pacific relatives, and larger egg size in the cool season compared to the warm season in both oceans (Figure 5; Table 3; Supplementary Table 3). However, both patterns were not present in all genera for all of the measurements of egg size. When those patterns differed it was generally due to failure to find a significant effect in one or the other of the datasets and not due to different measures of egg size producing conflicting strongly supported results. This suggests that despite the poor correlations between egg volume and egg weight or energy, the overall patterns of variation in egg size can be recovered with any of these three measures of egg size.

All three measure of egg size were larger for the Caribbean species than for the Pacific species in Acanthemblemaria, Coryphopterus, Ophioblennius, and Abudefduf (Table 3; Supplementary Table 3; Figures 5A,B,D,E; on which significant Tukey's HSD values are indicated). In Microspathodon egg volume was larger in the Pacific species than in the Caribbean species and the other two measures did not differ significantly between the species (Table 3; Figure 5G). In Stegastes, the S. acalpulcoensis-planifrons pair followed the general rule that the Caribbean species produces larger eggs than the Pacific species (Figure 5C). In the $S$. variabilis clade eggs from the Pacific species (S. flavilatus) were smaller than those from each of the three Caribbean species (Table 3; Figure 5H). The two Caribbean species from the two clades that lack Pacific members, $S$ leucostictus and S. partitus have the largest and smallest eggs, respectively, among the neotropical members of the genus (Supplemental Table 1). In Chromis egg dry weight and egg energy content were significantly lower in the Pacific species than in the Caribbean geminate (Table 3; Figure 5). In no case was there a clear-cut exception to the rule that Caribbean species have larger eggs in terms of content. 
Table 2 | Pearson Correlations between average egg volume, egg dry weight, and egg energy content within species of the 24 neotropical reef fishes studied.

\begin{tabular}{|c|c|c|c|c|}
\hline Species & Ocean & $\begin{array}{l}\text { Egg volume vs. } \\
\text { egg dry weight } r(n)\end{array}$ & $\begin{array}{l}\text { Egg volume vs. } \\
\text { egg energy } r(n)\end{array}$ & $\begin{array}{l}\text { Egg dry weight vs. } \\
\text { egg energy } r(n)\end{array}$ \\
\hline \multicolumn{5}{|l|}{ POMACENTRIDAE } \\
\hline Abudefduf troschelii & Pacific & $\mathbf{0 . 4 6 * *}(54)$ & $0.49 * * *(44)$ & $0.92^{* * *(44)}$ \\
\hline Chromis multilineata & Caribbean & - & - & $0.56 *(14)$ \\
\hline Microspathodon chrysurus & Caribbean & $0.25 \mathrm{~ns}(52)$ & $0.39 *(38)$ & $0.91 * * *(38)$ \\
\hline Microspathodon dorsalis & Pacific & $\mathbf{0 . 7 3} * *(32)$ & $0.75^{* * *}(24)$ & $0.98^{* * *(24)}$ \\
\hline Stegastes adustus & Caribbean & $\mathbf{0 . 4 0 * * ( 4 9 )}$ & $\mathbf{0 . 5 4 * * ( 4 0 )}$ & $0.97^{* * *}(40)$ \\
\hline Stegastes diencaeus & Caribbean & $0.55^{* *}(30)$ & $-0.02 \mathrm{~ns}(18)$ & $0.95^{* * *}(18)$ \\
\hline Stegastes leucostictus & Caribbean & $\mathbf{0 . 4 2 * *}(56)$ & $\mathbf{0 . 4 8 * *}(41)$ & $\mathbf{0 . 5 8 * * * ( 4 1 )}$ \\
\hline Stegastes. acapulcoensis & Pacific & $0.23 \mathrm{~ns}(37)$ & $0.32 \mathrm{~ns}(22)$ & $0.97^{* * *(22)}$ \\
\hline Stegastes flavilatus & Pacific & $0.54^{* * *(38)}$ & $\mathbf{0 . 5 1 * *}(27)$ & $0.98^{* * *}(27)$ \\
\hline \multicolumn{5}{|l|}{ BLENNIIDAE } \\
\hline Ophioblennius macclurei & Caribbean & $\mathbf{0 . 4 7 * *}(43)$ & $0.89 * * *(28)$ & $0.90 * * *(28)$ \\
\hline Ophioblennius steindachneri & Pacific & $0.35 \mathrm{~ns}(24)$ & $0.34 \mathrm{~ns}(24)$ & $0.97 * * *(24)$ \\
\hline \multicolumn{5}{|l|}{ CHAENOPSIDAE } \\
\hline Acanthemblemaria rivasi & Caribbean & $\mathbf{0 . 5 6 * *}(39)$ & $\mathbf{0 . 4 7 * * ( 3 6 )}$ & $0.97^{* * *(36)}$ \\
\hline Acanthemblemaria hancocki & Pacific & 0.23 ns (46) & $0.16 \mathrm{~ns}(42)$ & $\mathbf{0 . 8 3 * * * ( 4 2 )}$ \\
\hline \multicolumn{5}{|l|}{ GOBIIDAE } \\
\hline Coryphopterus dicrus & Caribbean & $-0.40 \mathrm{~ns}(11)$ & $-0.01 \mathrm{~ns}(11)$ & $\mathbf{0 . 8 2 * * ( 1 1 )}$ \\
\hline
\end{tabular}

Probability values (p): $n s>0.05 i^{*}<0.05 i^{* *}<0.01 i^{* * *}<0.001$. Calculated with JMP using the "Multivariate" menu. Due to missing values REML was used to calculate correlations. ND, no data.

Values in bold are significant at $p<0.05-0.01$.

Eggs from the cool season had statistically significantly larger volumes, dry weight, and energy content than those collected in the warm season for all genera except for: Chromis and Acanthemblemaria (Figures 5B,F; Table 3). For the two Chromis species there was no significant effect of season on dry weight. Power analysis indicates that a sample size of over 300 would be necessary to detect significance of the very small size indicated by our data (Supplemental Table 3). For C. atrilobata, the single species for which we have egg volumes, there was likewise no effect of season on egg volume. Adequate samples were not available to test for a seasonal effect on egg energy content for Chromis. For Acanthemblemaria, both egg dry weight and egg energy content were larger during the cool season, but there was no significant effect of season on egg volume. No species showed any tendency, statistically significant or otherwise, toward having smaller eggs (volume or content) in the cool season.

In five of seven genera there was a significant interaction between season and species (Figure 5; Table 3). In all cases when an interaction was present it showed a larger impact of season on egg size in the Pacific than in the Caribbean. For Abudefduf there was a significant effect of season on both egg weight and egg energy in the Pacific species, but not the Caribbean species (Table 3; Supplemental Table 3). In Microspathodon all species showed a significant effect of season on egg volume (a larger effect in the Pacific species; Figure 5G), but a significant effect on egg weight and energy content only in the Pacific species. For both clades of Stegastes egg volume showed a significantly stronger seasonal effect in the Pacific than the Caribbean (Figures 5C,H), but there was no significant interaction when egg weight or energy are analyzed. Ophioblennius showed a significant effect of season on egg volume in the Pacific species only (Figure 5E), but no interaction effect on egg weight or energy content (Table 3; Supplementary Table 3). Nor did that effect on volume remain in the analyses of clutches for which data on both volume and content were available. This suggests that the lack of a statistically significant interaction term 

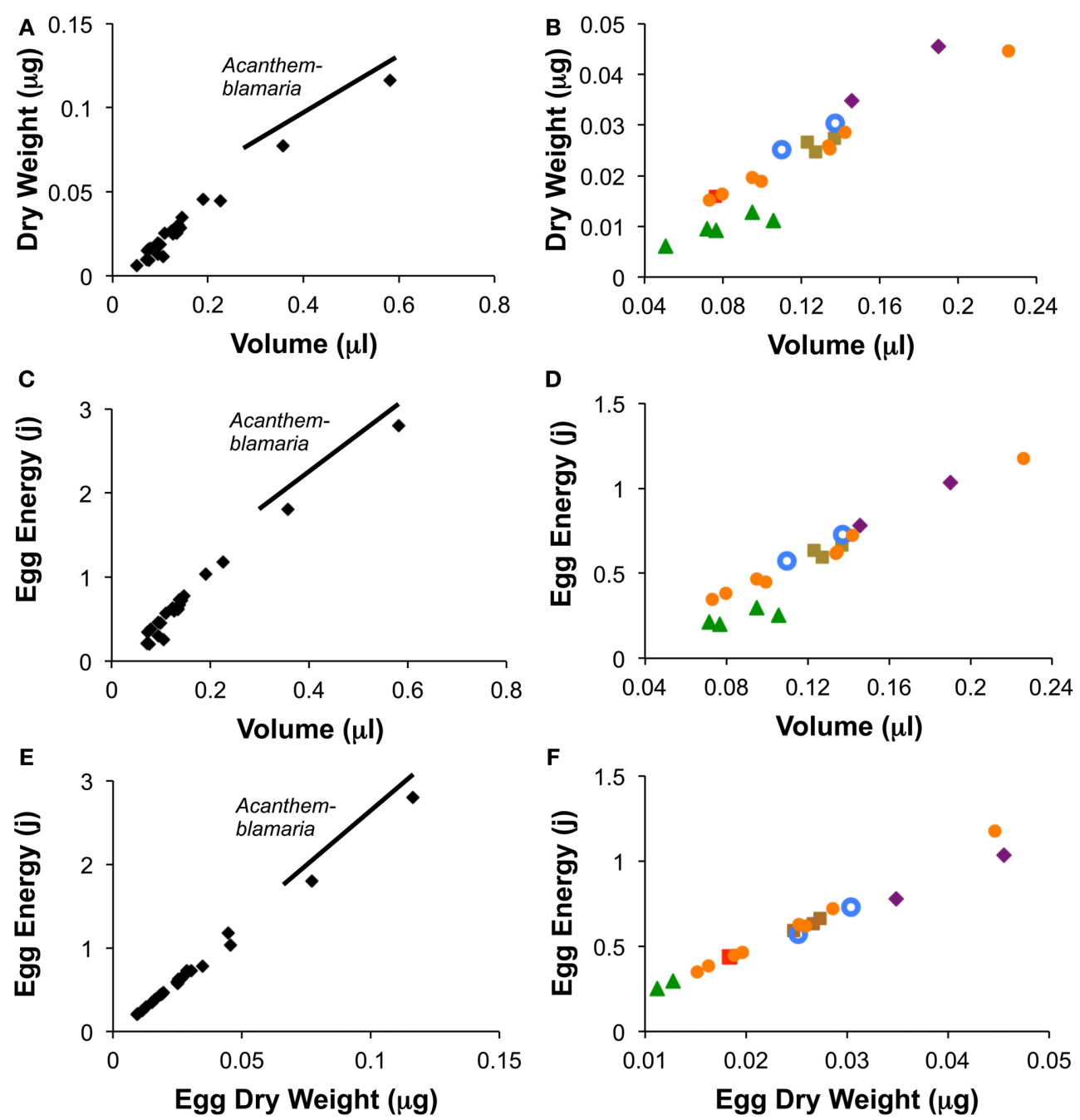

FIGURE 4 | Relationships between egg volume and egg dry weight $(A, B)$, volume and egg energy content $(C, D)$ and egg dry weight and egg energy content $(E, F)$ for the $\mathbf{2 4}$ species of neotropical fishes. Figures show species means for wet season data only. Graphs on the left $(\mathbf{A}, \mathbf{C}, \mathbf{E})$

in the analysis of egg weight or energy in this case is due to either small sample sizes or the distribution of dates sampled. The Acanthemblamaria species showed no significant difference in their response to season (Table 3; Supplemental Table 3; Figure 5B) and the Coryphopterus species also showed a very similar response of egg volume to season, although there was a marginally significant interaction between season and species (Table 3; Figure 5D).

\section{EGG-SIZE vs. TEMPERATURE}

There was a general tendency toward a decline in egg size with temperature across the entire set of species (Table 4). There were negative correlations between the average temperature for the week and egg volume in 18 of 24 species. Fifteen of the species showed a negative correlation between temperature and egg dry weight and 13 showed a negative correlation between temperature and egg energy content. Only four species did not include Acanthemblemaria while those on the right (B,D,F) eliminate this genus to show the other species in more detail. $\$$ = Abudefduf, $\square=$ Chromis, $\boldsymbol{\Delta}=$ Coryphopterus, $\mathbf{\square}=$ Microspathodon, $\odot=$ Ophioblennius, $\bullet=$ Stegastes.

show a significant correlation in any of the three measures: C. atralobata and M. bairdii from the Pacific and C. tortugae and $C$. dicrus from the Caribbean. The only species to show a significant positive correlation between egg energy content and temperature was the Pacific S. acapulcoensis. Measurements covered only samples from the wet season, and correlations for this species therefore are not comparable to the correlations for other Pacific species that covered the much larger temperature range over both seasons. Overall, the statistically insignificant relationships between temperature and egg volume or content, and non-significant relationships between temperature and egg dry weight or egg volume were typically associated with small sample sizes and/or reduced temperature ranges across which eggs were sampled. For example, power analysis suggests that for C. atrilobata a sample size of 48 (compared to our 21) could be sufficient to detect a significant effect of temperature on egg volume). 


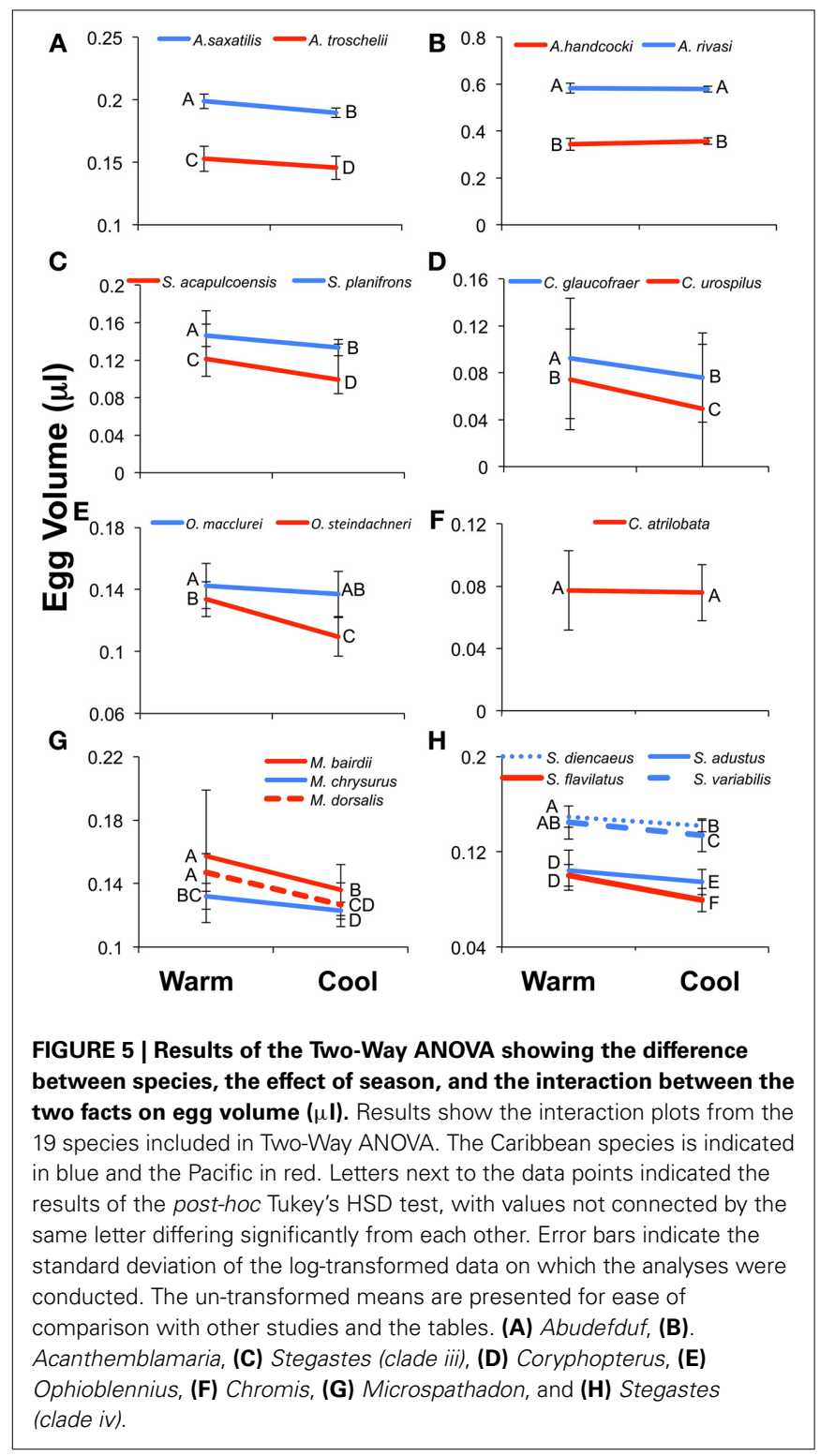

\section{DISCUSSION \\ RELATIONSHIPS BETWEEN EGG VOLUME, WEIGHT, AND ENERGY CONTENT}

We found that the relationship between dry weight and egg energy content is almost perfectly linear across the 24 tropical reef species studied (Figure 4). This suggests that these eggs are broadly similar in composition of lipids, proteins and carbohydrates. Egg volume is also a good predictor of egg dry weight and egg energy content among species, but these relationships are not quite so uniform across the genera. Across the entire range of volumes the relationship is fairly good. However, examining egg volumes under $0.25 \mu \mathrm{l}$ shows that the five species of Coryphopterus have a more gradual increase in dry weight and energy content with volume than do the other genera. Since Coryphopterus species are not outliers in the correlation between dry weight and energy (Figures $4 \mathrm{E}, \mathrm{F}$ ), this suggests that species in this genus have more highly hydrated eggs than eggs from the other groups. This may relate to natural nests of Coryphopterus species typically being in narrow-mouthed sandy burrows in the substratum in deeper habitat with no wave action. In such poorly ventilated situations relatively large egg surface-area may be important for embryo respiration.

Within species the relationship between egg volume, dry weight, and energy content is not so clear-cut. We found that, in general, the average volume of an egg is typically a poor predictor of the average weight or energy content of an egg in the same clutch (Table 2; Supplementary Table 2). Average dry weight of an egg in a clutch was however almost always a very good predictor of the average energy content of an egg in the same clutch. This applies irrespective of whether one or more females typically contribute to a clutch in the species examined. These relationships indicate that the extent of hydration (which effects volume but not dry weight or energy content) of an egg is not closely linked to the amount of material it contains. The close correlation between the average dry weight of an egg compared to the average energy content of an egg from the clutch also suggests that within clutch variation in egg content does not drive the poor relationship between egg volume and content. Volume/content relationships have been found to be stronger in interspecific comparisons than in within population comparisons in other fishes (Chambers, 1997), so this may be typical of fishes in general.

Despite the weakness of the volume/content relationship within species, seasonal differences in egg volume, dry weight, and energy content did follow the same general pattern in most of the species. When different results were obtained from analyses using these different proxies for egg size it was largely due to a failure to detect a significant effect in the datasets with small sample sizes. In no cases did the results from using egg volume differ significantly in direction from the results of the same analysis using egg dry weight. Thus, despite the large amount of unexplained variation in volume/content relationships within a single population, egg volume, which is significantly easier to measure than dry weight or energy content, does represent a useful eggsize indicator for comparing seasonal variation in egg-content as well as differences in egg-content among these closely related reef fishes.

\section{TRANSISTHMIAN VARIATION IN EGG-SIZE}

We hypothesized that if larval-food availability has an overriding influence on interspecific variation in egg size then eggs of Pacific species should be smaller than those of Atlantic geminates and, perhaps, other congeners. If temperature is of overriding importance, then Caribbean species should have smaller eggs than Pacific species, at least during the cool season, when Pacific temperatures are much lower. Our data show that eggs of Pacific members of seven genera from four families of reef fishes typically are smaller in volume and content than those of geminate or other congeneric Caribbean species, consistent with the hypothesis that productivity and not temperature is driving the differences between the two coasts. These differences parallel transisthmian differences in the sizes of hatchling larvae of many of the same fish species (Wellington and Robertson, 
Table 3 | Results of the Two-Way ANOVA of 3 different measurements of egg size.

\begin{tabular}{|c|c|c|c|c|}
\hline Genus & Effect of season & Effect of species & Season $\times$ species & $r^{2}$ and $N$ for the model \\
\hline \multicolumn{5}{|l|}{ POMACENTRIDAE } \\
\hline \multicolumn{5}{|c|}{ Abudefduf saxatilis vs. A. troschelii } \\
\hline Log egg volume & Dry $>$ wet $^{* * *}$ & Carib $>\mathrm{Pac} * * *$ & ns & $0.73,457$ \\
\hline Log egg dry weight & Dry $>$ wet $^{* *}$ & Carib $>\mathrm{Pac}^{* * *}$ & Pac: seasonal effect; Carib: no seasonal effect * & $0.70,120$ \\
\hline Log egg energy & Dry $>$ wet $^{* * *}$ & Carib $>\mathrm{Pac} * * *$ & ns & $0.67,92$ \\
\hline Culled log egg volume & Dry $>$ wet $^{* * *}$ & Carib $>\mathrm{Pac} * * *$ & Pac: seasonal effect; Carib: no seasonal effect * & $0.86,120$ \\
\hline \multicolumn{5}{|c|}{ Chromis multilineata vs. C. atrilobata } \\
\hline Log egg volume & ns (C. atrilobata only) & - & - & - \\
\hline Log egg dry weight & Ns & Carib $>\mathrm{Pac}^{* * *}$ & ns & $0.48,30$ \\
\hline Log egg energy & - & Carib $>\mathrm{Pac}^{* * *}$ & - & - \\
\hline
\end{tabular}

\section{Microspathodon bairdii, and M. dorsalis vs. M. chrysurus ${ }^{\#}$}

\begin{tabular}{|c|c|c|c|c|}
\hline Log egg volume & Dry $>$ wet $^{* * *}$ & Pac $>$ Carib*** & All: seasonal effect. Carib effect $<$ Pac effect. ${ }^{* *}$ & $0.48,465$ \\
\hline Log egg dry weight\& & Dry $>$ wet $^{* * *}$ & ns & Pac: seasonal effect; Carib: no seasonal effect. ** & $0.24,84$ \\
\hline Log egg energy\& & Dry $>$ wet $^{* * *}$ & ns & Pac: seasonal effect; Carib: no seasonal effect* & $0.26,62$ \\
\hline Culled log egg volume & Dry $>$ wet $^{* * *}$ & Pac $>$ Carib*** & All: seasonal effect. Carib effect $<$ Pac effect. ${ }^{* *}$ & $0.56,115$ \\
\hline
\end{tabular}

\section{Stegastes variabilis, $\boldsymbol{S}$. adustus and $\boldsymbol{S}$. diencaeus vs. S. flavilatus}

Log egg volume

Log egg dry weight

Dry $>$ wet $^{* *}$

Carib $>$ Pac ***

Log egg energy

Dry $>$ wet $^{*}$

Carib $>\mathrm{Pac}^{* * *}$

All: seasonal effect. Carib effect $<$ Pac effect. ***

$0.88,620$

Dry $>$ wet $^{*}$

Carib $>\mathrm{Pac}^{* * *}$

ns

$0.57,157$

$0.63,109$

\begin{tabular}{|c|c|c|c|c|}
\hline \multicolumn{5}{|c|}{ Stegastes acalpulcoensis vs. S. planifrons } \\
\hline Log egg volume & Dry $>$ wet $^{* * *}$ & Carib $>$ Pac $* * *$ & All: seasonal effect. Carib effect $<$ Pac effect. ${ }^{* * *}$ & $0.81,135$ \\
\hline Log egg dry weight & Dry $>$ wet $^{* \$}$ & Carib $>$ Pac $* * *$ & ns & $0.60,73$ \\
\hline \multicolumn{5}{|l|}{ BLENNIIDAE } \\
\hline \multicolumn{5}{|c|}{ Ophioblennius macclurei vs. steindachneri } \\
\hline Log egg volume & Dry $>$ wet $^{* * *}$ & Carib $>\mathrm{Pac} * * *$ & Pac: seasonal effect; Carib: no seasonal effect*** & $0.65,137$ \\
\hline Log egg dry weight & Dry $>$ wet $^{* * *}$ & Carib $>\mathrm{Pac} * * *$ & ns & $0.59,67$ \\
\hline Log egg energy & Dry $>$ wet $^{* * *}$ & Carib $>\mathrm{Pac} * * *$ & ns & $0.73,52$ \\
\hline Culled log egg volume & Dry $>$ wet $^{* * *}$ & Carib $>$ Pac $* * *$ & ns & $0.78,67$ \\
\hline \multicolumn{5}{|l|}{ CHAENOPSIDAE } \\
\hline \multicolumn{5}{|c|}{ Acanthemblemaria rivasi vs. hancocki } \\
\hline log egg volume & ns & Carib $>$ Pac $* * *$ & ns & $0.92,90$ \\
\hline log egg dry weight & Dry $>$ wet $^{* * *}$ & Carib $>\mathrm{Pac} * * *$ & ns & $0.81,82$ \\
\hline Log egg energy & Dry $>$ wet $^{* * *}$ & Carib $>$ Pac $* * *$ & ns & $0.84,78$ \\
\hline \multicolumn{5}{|l|}{ GOBIIDAE } \\
\hline \multicolumn{5}{|c|}{ Coryphopterus glaucofrenum vs. C. urospilus } \\
\hline Log egg volume & Dry $>$ wet $^{* * *}$ & Carib $>\mathrm{Pac}^{* * * \S}$ & All: seasonal effect. Carib effect $<$ Pac effect.* & $0.28,117$ \\
\hline Log egg dry weight & Dry $>$ wet $^{* * *}$ & Carib $>$ Pac $* * \star \S$ & ns & $0.50,92$ \\
\hline Log egg energy & - & - & - & \\
\hline
\end{tabular}

Comparisons between species and seasons for egg volume, egg weight, and egg energy content for geminate species or close relatives in each genus. Egg data were log transformed to reduce inequality among variances. ${ }^{*} p<0.05 ;{ }^{* *} p<0.01 ;{ }^{* * *} p<0.001 ; n s, p>0.05$. In the cases where the dataset for egg volume includes many more dates and much larger sample sizes than weights or energy content, the volume datasets were also "culled" to include only the dates for which the egg weight and egg energy content were also available.

§One-Way ANOVA on all species for the wet season only shows the Pacific species is significantly smaller than all of the Caribbean species.

\#Two outliers in the volume measurements removed.

$\$$ Becomes significant at $p<0.05$ when the non-significant interaction is removed.

\&Does not include M. bairdii.

2001) as well as transisthmian differences in egg-volume among echinoderms (Lessios, 1990) and bivalve molluscs (Marko and Moran, 2002; Moran, 2004) and proxies for hatching size in bryozoans (Jackson and Herrera, 1999) and molluscs (Fortunato, 2004).
While our data and similar transisthmian data on marine invertebrates support the larval-food hypothesis other scenarios cannot yet be ruled out. For example in food-rich environments growth rates are increased and predation pressure may be reduced making the rapid attainment of a size refuge from 
Table 4 | Pearson Correlations between average weekly temperature across years and egg volume, egg dry weight, and egg energy content within species of the 24 neotropical reef fishes studied.

\begin{tabular}{|c|c|c|c|c|}
\hline Species & Ocean & $\begin{array}{l}\text { Weekly temperature } \\
\text { vs. egg volume } r(n)\end{array}$ & $\begin{array}{l}\text { Weekly temperature } \\
\text { vs. egg dry weight } r(n)\end{array}$ & $\begin{array}{l}\text { Weekly temperature } \\
\text { vs. egg energy } r(n)\end{array}$ \\
\hline \multicolumn{5}{|l|}{ POMACENTRIDAE } \\
\hline Abudefduf saxatilis & Caribbean & $-0.250(374)^{* * *}$ & $-0.297(66)^{*}$ & $-0.348(48)^{*}$ \\
\hline Abudefduf troschelii & Pacific & $-0.40(83)^{* * *}$ & $-0.245(54) \mathrm{ns}$ & $-0.363(44)^{*}$ \\
\hline Chromis multilineata & Caribbean & - & $-0.422(15) \mathrm{ns}$ & $-0.068(14) \mathrm{ns}$ \\
\hline Chromis atrilobata & Pacific & $-0.293(21) \mathrm{ns}$ & $-0.223(15) \mathrm{ns}$ & $-0.580(6) \mathrm{ns}$ \\
\hline Microspathadon bairdii & Pacific & $-0.274(31) \mathrm{ns}$ & $0.248(16) \mathrm{ns}$ & $0.340(10) \mathrm{ns}$ \\
\hline Microspathodon chrysurus & Caribbean & $-0.472(350)^{* * *}$ & $-0.302(52)^{*}$ & $-0.245(38) \mathrm{ns}$ \\
\hline Microspathodon dorsalis & Pacific & $-0.683(86)^{* * *}$ & $-0.730(32)^{* * *}$ & $-0.846(24)^{* * *}$ \\
\hline Stegastes adustus & Caribbean & $-0.618(77)^{* * *}$ & $-0.347(49)^{*}$ & $-0.418(40)^{* *}$ \\
\hline Stegastes diencaeus & Caribbean & $-0.335(338)^{* * *}$ & $-0.394(30)^{*}$ & $0.382(18) \mathrm{ns}$ \\
\hline Stegastes leucostictus & Caribbean & $-0.326(91)^{* *}$ & $-0.589(56)^{* * *}$ & $-0.235(41) \mathrm{ns}$ \\
\hline Stegastes partitus & Caribbean & $-0.377(361)^{* * *}$ & $-0.469(51)^{* * *}$ & $-0.593(40)^{* * *}$ \\
\hline Stegastes planifrons & Caribbean & $-0.686(36)^{* * *}$ & $-0.383(36)^{*}$ & $-0.542(19)^{*}$ \\
\hline Stegastes variabilis & Caribbean & $-0.418(65)^{* * *}$ & $-0.595(40)^{* * *}$ & $-0.483(24)^{*}$ \\
\hline Stegastes. acapulcoensis & Pacific & $-0.850(99)^{* * *}$ & $-0.053(37) \mathrm{ns}$ & $0.498(22)^{*}$ \\
\hline Stegastes flavilatus & Pacific & $-0.875(140)^{* * *}$ & $-0.563(38)^{* * *}$ & $-0.521(27)^{* *}$ \\
\hline \multicolumn{5}{|l|}{ BLENNIIDAE } \\
\hline Ophioblennius macclurei & Caribbean & $-0.423(54)^{* *}$ & $-0.732(43)^{* * *}$ & $-0.834(28)^{* * *}$ \\
\hline Ophioblennius steindachneri & Pacific & $-0.715(83)^{* * *}$ & $-0.445(24)^{*}$ & $-0.471(24)^{*}$ \\
\hline \multicolumn{5}{|l|}{ CHAENOPSIDAE } \\
\hline Acanthemblemaria rivasi & Caribbean & $-0.031(40) \mathrm{ns}$ & $-0.609(39)^{* * *}$ & $-0.537(36)^{* * *}$ \\
\hline Acanthemblemaria hancocki & Pacific & $0.238(50) \mathrm{ns}$ & $-0.530(46)^{* * *}$ & $-0.447(42)^{* *}$ \\
\hline \multicolumn{5}{|l|}{ GOBIIDAE } \\
\hline Coryphopterus dicrus & Caribbean & $-0.058(14) \mathrm{ns}$ & $0.125(11) \mathrm{ns}$ & $-0.016(11) \mathrm{ns}$ \\
\hline Coryphopterus glaucofrenum & Caribbean & $-0.441(65)^{* * *}$ & $-0.472(48)^{* * *}$ & $-0.126(20) \mathrm{ns}$ \\
\hline Coryphopterus personatus & Caribbean & $-0.425(28)^{*}$ & $0.034(28) \mathrm{ns}$ & $-0.047(28) \mathrm{ns}$ \\
\hline Coryphopterus tortugae & Caribbean & $0.084(29) \mathrm{ns}$ & $0.121(27) \mathrm{ns}$ & $0.104(27) \mathrm{ns}$ \\
\hline Coryphopterus urospilus & Pacific & $-0.651(53)^{* * *}$ & $-0.733(45)^{* * *}$ & $-0.532(30)^{* *}$ \\
\hline
\end{tabular}


calculate correlations.

Values in bold are significant at $p<0.05-0.01$.

predation less important. This may result in the production of smaller and more numerous offspring when primary productivity is high. One obvious abiotic difference between the oceans, salinity (see Alory et al., 2012), is unlikely to explain our observed pattern as low salinity generally correlates with larger egg size or offspring size (Solemdal, 1967; Vallin and Nissling, 2000; Gimenez and Anger, 2001; and see Chambers, 1997), the opposite of our observed inter-oceanic and seasonal differences. Other abiotic factors that also differ strongly in inshore waters on the two sides of the Isthmus of Panama and might also affect reproductive activity of fishes include natural ocean acidification (e.g., Manzello et al., 2008) and reduced $\mathrm{O}_{2}$ levels (D'Croz and O'Dea, 2007) in surface waters associated with upwelling activity along the Pacific coast of Panama. Recent manipulative experiments have assessed effects of ocean acidification, sometimes in association with increased temperatures, on egg development and early life histories of marine fishes. Those manipulations resulted in little or no effect on egg size and development and hatchling-size of various tropical and temperate fishes (Munday et al., 2009; Franke and Clemmensen, 2011; Miller et al., 2012; Hurst et al., 2013), although acidified conditions can either increase (Munday et al., 2009) or decrease larval growth (Franke and Clemmensen, 2011). Acidification can also stimulate higher reproductive output, perhaps at cost to egg volume and hatchling size (Miller et al., 2013). What significance this work has to predict potential effects of upwelling on Tropical Eastern Pacific fishes is unclear, as none of those acidification experiments examined effects of reduced $\mathrm{pH}$ at lower temperatures and $\mathrm{O}_{2}$ levels, a combination characteristic of upwelling conditions.

\section{SEASONAL VARIATION IN EGG-SIZE}

We hypothesized that if larval food availability has an overriding influence on intraspecific variation in egg size then egg-size should be minimal during the cool season in Pacific species, and show little seasonal pattern of change among Caribbean species. If, on the other hand, temperature has an over-riding effect then seasonal variation in egg size should be negatively related 
to temperature on both sides of the Isthmus. Our data show that none of the Pacific species produced smaller eggs (volume and content) during the cooler, higher productivity season, and that egg size changed seasonally in Pacific species and in some Caribbean species despite the lack of distinct seasonal change in productivity in the Caribbean. Thus, the hypothesis that seasonal change in egg size is an adaptive response to variation in the supply of larval food (Cushing, 1967; Hempel and Blaxter, 1967; Bagenal, 1971) is not supported by our data, nor by data from Mediterranean (Daoulas and Economou, 1986) and Hawaiian (Clarke, 1989) fishes.

Species from both sides of the Isthmus show a significant decrease of egg size with increasing temperatures. The patterns of cool vs. warm seasonal change in egg size as well as the negative correlation between egg size and average weekly temperature support the idea that temperature has an overriding effect on egg size variation within species. The significant interactions between season and species in our Two-Way ANOVAs support the role of temperature in controlling intraspecific variation in egg size. Six out of nine comparisons between Pacific and Caribbean pairs showed a significant interaction between ocean (i.e., species) and season. In all of these the Pacific species showed either a larger effect of season than did the Caribbean species, or no effect of season was recovered for the Caribbean (Table 3). Thus, the Pacific, the site with the largest temperature change across the seasons, has the largest change in egg size across the seasons, while species from the Caribbean which has a minimal change in temperature show smaller or no changes in egg size with season. These patterns are consistent with evidence from various marine metazoan taxa that egg size and offspring size virtually always show a negative correlation with environmentally relevant temperatures (Atkinson et al., 2001). This includes Panamanian slipper limpets, which produce larger diameter eggs and larger hatchlings when reared at cooler temperatures (Collin, 2012).

\section{POTENTIAL EFFECTS OF MATERNAL CONDITION AND SIZE ON SEASONAL VARIATION IN EGG SIZE?}

Maternal condition and size are well known to influence variation in egg-size in fishes (Chambers and Leggett, 1996; Kerrigan, 1997; Heath and Blouw, 1998; Kokita, 2003; McCormick, 2003), with larger females or those in better condition producing larger eggs. Could the seasonal patterns of variation in egg size and content that we found be due to either maternal factor? On both sides of the isthmus spawning is reduced during the cool period, often severely so on the Pacific coast. This suggests that environmental conditions during the cool season on both coasts are stressful for reef fishes. On the Caribbean coast strong, persistent onshore trade winds produce turbid conditions, and stronger surge and current flows on shallow reefs. On the Pacific side, cool season upwelling produces very low temperatures, reduced oxygen levels and reduced pH (see Table 1; D'Croz and O'Dea, 2007; Manzello et al., 2008). In the Pacific spawning often ceases during intensive upwelling, but continues at a reduced level during El Niño events, when upwelling activity is weaker and temperatures are higher than normal (Robertson, 1990). It seems unlikely that environmental conditions that inhibit spawning would be associated with improved female condition, resulting in the observed pattern of larger eggs during the cool season. It also seems unlikely that seasonal variation in female size produces such seasonal variation in egg size. Those of our study species for which demographic data are available live for at least several years (Meekan et al., 2001; Caldow and Wellington, 2003). In addition, larval recruitment of those species is spread throughout most of the year (Robertson, 1989, 1990, 1992). A combination of these two characteristics would provide a year-round mixture of sizes of breeding females. At this point there is little support for the idea that seasonal variation in maternal condition and size drive the seasonal pattern of variation in egg size, although this hypothesis remains to be tested explicitly.

\section{TEMPERATURE EFFECTS ON EGG SIZE: A BYPRODUCT OF PHYSIOLOGICAL CONSTRAINTS OR ADAPTIVE VARIATION?}

On a species by species basis negative relationships between temperature and offspring size have often been explained as adaptive and involving specific aspects of each species' natural history. However it seems unlikely that such a diversity of organisms, phylogenetic histories and ecologies would consistently produce the same negative relationship (cf. Atkinson et al., 2001). For example, our observations show a consistently negative relationship between temperature and egg size among species in different families and suborders of fishes, taxa with a range of adult and larval ecologies that live in two oceans with differing oceanographic conditions. Species in some of those taxa exhibit a variety of patterns of seasonal change in larval recruitment with no consistent relationship to environmental factors thought to be primary determinants of larval survivorship (Robertson, 1990).

The ubiquity of the egg size temperature relationship has prompted the proposal that physiological constraints underlie the OTSR. The rates of growth and development of eggs may be affected differently by temperature, and if the temperature coefficient $\left(\mathrm{Q}_{10}\right)$ of egg-development rate is greater than that of egg-growth rate, this difference could lead to larger eggs at colder temperatures (e.g., Zuo et al., 2012). This idea has been proposed to explain the negative relationship between temperature and egg size for fishes (Chambers, 1997; Daoulas and Economou, 1986) and butterflies (Steigenga and Fischer, 2007). A similar constraint hypothesis, that all cells are larger at cooler temperatures and that eggs are simply just another cell type (Van Voorhies, 1996), could be tested by measuring the seasonal patterns of variation in size of both eggs and other cell types with fast turn-over rates, or by manipulating temperature in a laboratory setting to control for effects of other environmental cues. Concurrent, concordant temperature related variation in the size of eggs and other cells would lend support to Van Voorhies' hypothesis. Such an approach has provided some evidence of increased size in somatic cells with decreasing temperatures in other ectotherms (Azevedo et al., 2002; Arendt, 2007). Temperature also has effects on hormone systems that influence reproduction (Fraser et al., 2002) as well as oogenesis and egg-size and hatchling size (McCormick, 1999). Other mechanisms for physiological constraints include allometric differences of oxygen diffusion and metabolic rate in embryos or egg masses (Woods, 1999; Woods and Hill, 2004).

The physiological constraint hypothesis implies that variation in egg size with temperature is non-adaptive, at least with respect 
to effects on embryonic or larval survivorship. As Chambers (1997) pointed out, deviations from this pattern could be particularly informative, because they could indicate an adaptive response. In the species we examined there is a large amount of variation in egg size. In these tropical species, particularly the Caribbean species which live in a low seasonality environment, and in which there are no consistent connections between larval survivorship and environmental variation (Robertson, 1990; Wellington and Robertson, 2001), seasonal egg-size variation may have no adaptive significance. There is accumulating evidence that, in diverse taxa of fishes from very different environments, seasonal variation in egg size does not offset the effects of environmental change on larval survivorship (Daoulas and Economou, 1986; Clarke, 1989; and see Robertson, 1990). Although some species appear to closely fit idealized relationships between egg size, productivity and temperature, a broad-based interspecific comparative approach assessing as many aspects of reproduction and environmental parameters as possible is necessary to understand what aspects of intraspecific variation in egg size are adaptive and what are due to phylogenetic or physiological constraints (Leis et al., 2013).

Although it may be unlikely that a diversity of organisms, phylogenetic histories and ecologies would produce a consistent OTSR, adaptive hypotheses still need to be considered. Such hypotheses range from general explanations relevant to a broad range of unrelated taxa with differing modes of reproduction, to those specifically tailored to a particular mode of reproduction and environmental circumstance. As with any kind of phenotypic plasticity, the OTSR may have originated from a physiological constraint, and subsequently been modified by selection to become adaptive (Eshel and Matessi, 1998; Hughes et al., 2003).

A general hypothesis relates to size-dependent effects of temperature on larval performance and survival. Small larvae from small eggs experience reduced survivorship in some fishes (e.g., Iguchi and Yamaguchi, 1994). Small fish larvae have reduced swimming performance under colder conditions due to temperature effects on water viscosity, and the metabolic cost of swimming increases at low temperatures (Hunt von Herbing, 2002). These effects may be too small in warm waters to be of significance to fishes on the Caribbean coast of Panama, and other consistently warm areas. However, seasonal changes in temperature in eastern Pacific upwelling zones may be sufficiently great $\left(10-15^{\circ} \mathrm{C}\right)$ to affect larval performance, and survivorship in a size-dependent manner among fishes and other marine organisms. Production of larger eggs at colder temperatures might compensate for this effect. The fact that the Pacific species with the largest eggs shows almost no seasonal change in egg size (Figure 5B) offers support for this view.

A more specific hypothesis is relevant to some of our study species on both sides of the Isthmus. Clarke (1989) found that the negative relationship between egg- and hatchling-size and temperature in a tropical anchovy is adaptively linked to temperature effects on development of the egg to hatching: Temperature controls the rate of development of the larva in the egg and, hence, when it becomes competent to begin feeding. As the transition to first-feeding is a critical stage in the life history of pelagic fish larvae, and the larvae of this anchovy feed only during the day, a failure to reach the most appropriate stage of development at the stage of the diel cycle that maximizes first-feeding opportunities may increase mortality of new hatchlings. Hence a combination of seasonal variation in the time of day of spawning and eggsize may allow developing larvae to achieve competency as the window of opportunity for first feeding arrives, regardless of the season (Clarke, 1989).

This "egg-development window" hypothesis could apply to some of our study species in the following way. In Stegastes species, at least, hatching appears to be restricted to a short period just after sunset, while spawning in some of the same species for which data are available occurs in the early morning (Petersen, 1990; Petersen and Hess, 1990; Robertson et al., 1990). In these species eggs develop rapidly and hatch 3-5 days after spawning. A failure to achieve an appropriate state of development during the hatching window would result in the larva spending an additional day in the egg, a substantial delay that could increase mortality through loss of eggs in the nest and through consumption of larval energy reserves. On the Caribbean coast of Panama, where temperatures vary seasonally by only $\sim 3^{\circ} \mathrm{C}$, clutches of some of our Stegastes species do sometimes remain in the nest a day longer in the cool season than in warm season (Robertson, unpublished observations). Hence the prospect of a 1-day delay in hatching is real, even in this low seasonality environment. Adaptive seasonal variation in egg-size could ensure that larvae are at an appropriate stage of development when a narrow hatching window arrives regardless of the season.

There is tremendous variation among fishes in reproductive characteristics: in average egg-size; whether eggs are demersal, brooded or pelagic; whether or not there is parental care; to what extent there are spawning/hatching/first-feeding windows of opportunity; and the duration and timing of spawning seasons. Various formulations of the developmental-windows hypothesis that reflect this diversity of reproductive characteristics have the potential to account for a range of seasonal and latitudinal patterns of variation in egg-size. This hypothesis is more likely to be applicable to tropical species whose eggs develop rapidly than temperate species that take much longer to complete development not only because precise adjustments to the developmental sequence likely will be less feasible in the latter, but also because the relative energetic costs of a delay likely will be lower.

\section{ACKNOWLEDGMENTS}

Fieldwork was support by the Smithsonian Tropical Research Institute and by a grant from the National Geographic Society (NGS No.4610-91) to D. Ross Robertson. The Government of the Republic of Panama and the Guna (Kuna) General Congress provided permission for fieldwork (the latter for work in San Blas). Assistance with collection and processing of eggs was provided by E. Pena (in particular), plus K. Andersen, A. Cedeno, L. Fore, C. Guerra, L. Gutierrez, J. Hampel, J. Harding, H. Hess, J. Jolly, K. Marchetti, A. Lent, K. Niesen, E. Paredes, D. Pilson, R. Riley, U. Schober, S. Swearer, and C. White. Sea water temperature data were provided by the Smithsonian Tropical Research Institute's Environmental Monitoring Program. Thanks to one of the referees for nudges about some of our methodology, and potential explanations for our results. 


\section{SUPPLEMENTARY MATERIAL}

The Supplementary Material for this article can be found online at: http://www.frontiersin.org/journal/10.3389/fevo.2014. 00084/abstract

\section{REFERENCES}

Allen, R. M., and Marshall, D. (2014). Egg size effects across multiple life-history stages in the marine annelid Hydroides diramphus. PLoS ONE 9:e102253. doi: 10.1371/journal.pone.0102253

Alory, G., Maes, C., Delcroix, T., Reul, N., and Illig, S. (2012). Seasonal dynamics of sea surface salinity off Panama: the far eastern Pacific fresh pool. J. Geophys. Res. 117, C04028. doi: 10.1029/2011JC007802

Arendt, J. (2007). Ecological correlates of body size in relation to cell size and cell number: patterns in flies, fish, fruits and foliage. Biol. Rev. 82, 241-256. doi: 10.1111/j.1469-185X.2007.00013.x

Atkinson, D., Morley, S. A., Weetman, D., and Hughes, R. N. (2001). "Offspring size responses to maternal temperature in ectotherms," in Environment and Animal Development: Genes, Life Histories and Plasticity, eds D. Atkinson and M. Thorndyke (Oxford: BIOS), 269-285.

Azevedo, R. B. R., French, V., and Partridge, L. (2002). Temperature modulates epidermal cell size in Drosophila melanogaster. J. Insect Physiol. 48, 231-237. doi: 10.1016/S0022-1910(01)00168-8

Bagenal, T. B. (1971). The relation of the size of fish eggs, the date of spawning and the production cycle. J. Fish. Biol. 3, 207-219. doi: 10.1111/j.10958649.1971.tb03665.x

Bailey, K. N., and Heath, M. R. (2001). Spatial variability in the growth rate of blue whiting (Micromesistius poutassou) larvae at the shelf edge southwest of the UK. Fish. Res. 50, 73-87. doi: 10.1016/S0165-7836(00)00243-5

Bermingham, E., McCafferty, S. S., and Martin, A. (1997). "Fish biogeography and molecular clocks: perspectives from the Panamanian isthmus," in Molecular Systematics of Fishes, eds T. D. Kocher, and C. A. Stepien (New York, NY: Academic Press), 113-128.

Bernardo, J. (1996). The particular maternal effect of propagule size, especially egg size: patterns, models, quality of evidence and interpretations. Am. Zoo. 36, 216-236.

Brown, J. J., Ehtisham, A., and Conover, D. O. (1998). Variation in larval growth rate among striped bass stocks from different latitudes. Trans. Am. Fish. Soc. $127,598-610$.

Caldow, C., and Wellington, G. M. (2003). Patterns of annual increment formation in otoliths of pomacentrids in the tropical western Atlantic: implications for population age-structure examination. Mar. Ecol. Prog. Ser. 265, 185-195. doi: $10.3354 /$ meps 265185

Chambers, R. C. (1997). "Environmental influences on egg and propagule sizes in marine fishes," in Early Life History and Recruitment in Fish Populations, eds R. C. Chambers and E. A. Trippel (Melbourne, VIC: Chapman and Hall), 63-102.

Chambers, R. C., and Leggett, W. C. (1996). Maternal influences on variation in egg sizes in temperate marine fishes. Am. Zoo. 36, 180-196.

Clarke, T. A. (1989). Seasonal differences in spawning, egg size and early development times of the Hawaiian Anchovy or Nehu, Encrasicholina purpurea. Fish. Bull. 87, 593-600.

Collin, R. (2003). World-wide patterns of development in calyptraeid gastropods. Mar. Ecol. Prog. Ser. 247, 103-122. doi: 10.3354/meps 247103

Collin, R. (2012). Temperature-mediated trade-offs in the life histories of two slipper limpets (Gastropoda: Calyptraeidae) with planktotrophic development. Biol. J. Linn. Soc. 106, 763-775. doi: 10.1111/j.1095-8312.2012.01908.x

Craik, J. C. A., and Harvey, S. M. (1984). Biochemical changes occurring during final maturation of eggs of some marine and freshwater teleosts. J. Fish. Biol. 24, 599-610. doi: 10.1111/j.1095-8649.1984.tb04830.x

Cushing, D. H. (1967). The grouping of herring populations. J. Mar. Biol. Assoc. U.K. 47, 193-208. doi: 10.1017/S002531540003366X

Daoulas, C., and Economou, A. N. (1986). Seasonal variation of egg size in the sardine, Sardina pilchardus Walb., of the Saronikos Gulf: causes and a probable explanation. J. Fish Biol. 28, 449-457. doi: 10.1111/j.1095-8649.1986. tb05182.x

D’Croz, L., and Robertson, D. R. (1997). “Coastal oceanographic conditions affecting coral reefs on both sides of the Isthmus of Panama,"in Proceedings of the 8th International Coral Reef Symposium, Vol. 2 (Panama City).
D’Croz, L., and O’Dea, A. (2007). Variability in upwelling along the Pacific shelf of Panama and implications for the distribution of nutrients and chlorophyll. Estuar. Coast. Shelf Sci. 73, 325-340. doi: 10.1016/j.ecss.2007.01.013

Einum, S., and Fleming, I. A. (2002). Does within-population variation in fish egg size reflect maternal influences on optimal values? Am. Nat. 160, 756-765. doi: $10.1086 / 343876$

Eshel, I., and Matessi, C. (1998). Canalization, genetic assimilation and preadaptation. A quantitative genetic model. Genetics 149, 2119-2133.

Eytan, R. I., Hastings, P. A., Holland, B. R., and Hellberg, M. E. (2012). Reconciling molecules and morphology: molecular systematics and biogeography of Neotropical blennies (Acanthemblemaria). Mol. Phylogenet. Evol. 62, 159-173. doi: 10.1016/j.ympev.2011.09.028

Fischer, K., Brakefield, P. M., and Zwaan, B. J. (2003). Plasticity in butterfly egg size: why larger offspring at lower temperatures? Ecology 84, 3138-3147. doi: 10.1890/02-0733

Fleming, I. A., and Gross, M. R. (1990). Latitudinal clines: a trade-off between egg number and size in Pacific salmon. Ecology 71, 1-11. doi: 10.2307/1940241

Fortunato, H. (2004). Reproductive strategies in gastropods across the Panama seaway. Invertebr. Reprod. Dev. 46, 139-148. doi: 10.1080/07924259.2004.9652617

Franke, A., and Clemmensen, C. (2011). Effect of ocean acidification on early life stages of Atlantic herring (Clupea harengus L.). Biogeosciences 8, 3697-3707. doi: 10.5194/bg-8-3697-2011

Fraser, E. J., Bosma, P. T., Trudeau, V. L., and Docherty, K. (2002). The effect of water temperature on the GABAergic and reproductive systems in female and male goldfish (Carassius auratus). Gen. Comp. Endocrinol. 125, 163-175. doi: 10.1006/gcen.2001.7714

Gimenez, L., and Anger, K. (2001). Relationships among salinity, egg size, embryonic development, and larval biomass in the estuarine crab Chasmagnathus granulata Dana, 1851. J. Exp. Mar. Biol. Ecol. 260, 241-257. doi: 10.1016/S00220981(01)00258-1

Heath, D. D., and Blouw, D. M. (1998). "Are maternal effects in fish adaptive or merely physiological side effects," in Maternal Effects as Adaptation, eds T. A. Mousseau and C. W. Fox (New York, NY: Oxford U Press), 178-200.

Heath, M. R. (1992). Field investigations of the early life stages of marine fish. $A d v$. Mar. Biol. 28, 1-174. doi: 10.1016/S0065-2881(08)60039-5

Hempel, G., and Blaxter, J. H. S. (1967). Egg weight in Atlantic herring (Clupea harengus L.). J. Cons. Int. Explor. Mer. 31, 170-195. doi: 10.1093/icesjms/31.2.170

Houde, E. D. (1989). Comparative growth, mortality, and energetics of marine fish larvae: temperature and implied latitudinal effects. Fish. Bull. 87, 471-495.

Houde, E. D., and Zastrow, C. E. (1993). Ecosystem and taxon-specific dynamic and energetics properties of larval fish assemblages Bull. Mar. Sci. 53, 290-335.

Hughes, K. A., Burleson, M. H., and Rodd, F. H. (2003). "Is phenotypic plasticity adaptive?", in The Biodemography of Human Reproduction and Fertility, eds J. Rogers and H.-P. Kohler (New York, NY: Springer), 23-42.

Hunt von Herbing, I. (2002). Effects of temperature on larval fish swimming performance: the importance of physics and physiology. J. Fish. Biol. 61, 865-876. doi: 10.1111/j.1095-8649.2002.tb01848.x

Hurst, T. P., Fernandez, E. R., and Mathis, J. T. (2013). Effects of ocean acidification on hatch size and larval growth of walleye pollock (Theragra chalcogramma). ICES J. Mar.Sci. 70, 812-822. doi: 10.1093/icesjms/fst053

Iguchi, K., and Yamaguchi, M. (1994). Adaptive significance of inter- and intrapopulational egg size variation in Ayu Plecoglossus altivelis (Osmeridae). Copeia 1994, 184-190. doi: 10.2307/1446684

Jackson, J. B. C., and Herrera, C. A. (1999). "Adaptation and constraint as determinants of zooid and ovicell size among encrusting ascophoran cheilostome Bryozoa from opposite sides of the Isthmus of Panama," in Proceedings of the 11th International Bryozoan Association Conference (Panama City).

Jaeckle, W. B. (1995). "Variation in egg size, energy content, and composition of invertebrate eggs: correlates to the mode of larval development," in Marine Invertebrate Larvae, ed L. McEdward (Boca Raton, FL: CRC Press), 49-77.

Johnston, T. A., and Leggett, W. C. (2002). Maternal and environmental gradients in the egg size of an iteroparous fish. Ecology 83, 1777-1791. doi: 10.1890/00129658(2002)083[1777:MAEGIT]2.0.CO;2

Jordan, D. S. (1908). The law of geminate species. Am. Nat. 17, 73-80. doi: $10.1086 / 278905$

Kaufman, K., and Thompson, R. C. (2005). Water temperature variation and the meteorological and hydrographic environments of Bocas del Toro, Panama. Caribb. J. Sci. 41, 392-413. 
Kerrigan, B. A. (1997). Variability in larval development of the tropical reef fish Pomacentrus amboinensis (Pomacentridae): the parental legacy. Mar. Biol. 127, 395-402. doi: 10.1007/s002270050026

Kokita, T. (2003). Potential latitudinal variation in egg size and number of a geographically widespread reef fish, revealed by common-environment experiments. Mar. Biol. 143, 593-601. doi: 10.1007/s00227-003-1104-x

Leis, J. M., and McCormick, M. (2002). "The biology, behavior and ecology of the pelagic, larval stage of coral reef fishes," in Coral Reef Fishes: Dynamics and Diversity in a Complex Ecosystem, ed P. F. Sale (New York, NY: Academic Press), 171-200.

Leis, J. M., Caselle, J. E., Bradbury, I. R., Kristiansen, T., Llopiz, J. K., Miller, M. J., et al. (2013). Does fish larval dispersal differ between high and low latitudes? Proc. R. Soc. Lond. B. Biol. Sci. 280:20130327. doi: 10.1098/rspb.2013.0327

Lessios, H. A. (1990). Adaptation and phylogeny as determinants of egg size in echinoderms from the two sides of the Isthmus of Panama. Am. Nat. 135, 1-13. doi: $10.1086 / 285028$

Manzello, D. P., Kleypas, J. A., Budd, D. A., Eakin, C. M., Glynn, P. W., and Langdon, C. (2008). Poorly cemented coral reefs of the eastern tropical Pacific: possible insights into reef development in a high- $\mathrm{CO}_{2}$ world. Proc. Natl. Acad. Sci. U.S.A. 105, 10450-10455. doi: 10.1073/pnas.0712167105

Marko, P. B., and Moran, A. L. (2002). Correlated evolutionary divergence of egg size and a mitochondrial protein across the Isthmus of Panama. Evolution 56, 1303-1309. doi: 10.1111/j.0014-3820.2002.tb01442.x

Marteinsdottir, G., and Able, K. W. (1988). Geographic variation in egg size among populations of the Mummichog, Fundulus heteroclitus (Pisces: Fundulidae). Copeia 1988, 471-478. doi: 10.2307/1445889

McCormick, M. I. (1999). Experimental test of the effect of maternal hormones on larval quality of a coral reef fish. Oecologia 118, 412-422. doi: $10.1007 / \mathrm{s} 004420050743$

McCormick, M. I. (2003). Consumption of coral propagules after mass spawning enhances larval quality of damselfish through maternal effects. Oecologia 136, 37-45. doi: 10.1007/s00442-003-1247-y

McEdwards, L. R., and Carson, S. F. (1987). Variation in egg organic content and its relationship with egg size in the starfish Solaster stimpsoni. Mar. Ecol. Prog. Ser. 37, 159-169. doi: 10.3354/meps037159

McEdwards, L. R., and Coulter, L. K. (1987). Egg volume and energy content are not correlated among sibling offspring of starfish: implications for life history theory. Evolution 41, 914-917. doi: 10.2307/2408900

Meekan, M. G., Ackerman, J., and Wellington, G. M. (2001). Demography and age structures of coral reef damselfishes in the tropical eastern Pacific ocean. Mar. Ecol. Prog. Ser. 212, 223-232 doi: 10.3354/meps 212223

Meekan, M. G., Carleton, J. H., McKinnon, A. D., Flynn, K., and Furnas, M. (2003). What determines the growth of tropical reef fish larvae in the plankton: food or temperature? Mar. Ecol. Prog. Ser. 256, 193-204. doi: 10.3354/meps256193

Miller, G. M., Watson, S.-A., Donelson, J. M., McCormick, M. I., and Munday, P. L. (2012). Parental environment mediates impacts of increased carbon dioxide on a coral reef fish. Nat. Clim. 1599, 858-861. doi: 10.1038/nclimate1599

Miller, G. M., Watson, S.-A., McCormick, M. I., and Munday, P. L. (2013). Increased $\mathrm{CO}_{2}$ stimulates reproduction in a coral reef fish. Glob. Change Biol. 19, 3037-3045. doi: 10.1111/gcb.12259

Moran, A. L. (2004). Egg size evolution in tropical American archid bivalves: the comparative method and the fossil record. Evolution 58, 2718-2733. doi: 10.1111/j.0014-3820.2004.tb01624.x

Moran, A. L., and McAlister, J. S. (2009). Egg size as a life history characteristics of marine invertebrates: is it all it's cracked up to be. Biol. Bull. 216, 226-242.

Munday, P. L., Donelson, J. M., Dixson, D. L., and Endo, G. G. K. (2009). Effects of ocean acidification on the early life history of a tropical marine fish. Proc. $R$. Soc. Lond. B. Biol. Sci. 276, 3275-3283. doi: 10.1098/rspb.2009.0784

Muss, A., Robertson, D. R., Stepien, C. A., Wirtz, P., and Bowen, B. W. (2001). Phylogeography of Ophioblennius: the role of ocean currents and geography in reef fish evolution. Evolution 55, 561-572. doi: 10.1554/00143820(2001)055[0561:POOTRO]2.0.CO;2

Padilla, D. K., and Adolph, S. C. (1996). Plastic inducible morphologies are not always adaptive: the importance of time delays in a stochastic environment. Evol. Ecol. 10, 105-117. doi: 10.1007/BF01239351

Petersen, C. W. (1990). The occurrence and dynamics of clutch loss and filial cannibalism in two Caribbean damselfishes. J. Exp. Mar. Biol. Ecol. 135, 141-146. doi: 10.1016/0022-0981(90)90011-Z
Petersen, C. W., and Hess, H. C. (1990). The adaptive significance of spawning synchronization in the Caribbean damselfish Stegastes dorsopunicans (Poey). J. Exp. Mar. Biol. Ecol. 151, 155-167. doi: 10.1016/0022-0981(91)90122-D

Rilling, G. C., and Houde, E. D. (1999). Regional and temporal variability in growth and mortality of bay anchovy, Anchoa mitchilii, larvae in Chesapeake Bay. Fish. Bull. 97, 555-569.

Riss-Vestergaard, J. (2002). Energy density of marine pelagic fish eggs. J. Fish. Biol. 60, 1511-1528. doi: 10.1111/j.1095-8649.2002.tb02444.x

Robertson, D. R. (1989). "Settlement and population dynamics of Abudefduf saxatilis on patch reefs in Caribbean Panama,"in Proceedings Sixth International Symposium Coral Reefs, Vol. 2 (Townsville, QLD).

Robertson, D. R. (1990). Differences in the seasonalities of spawning and recruitment of some small neotropical reef fishes. J. Exp. Mar. Bio. Ecol. 144, 49-62. doi: 10.1016/0022-0981(90)90019-9

Robertson, D. R. (1992). Patterns of lunar settlement and early-recruitment in Caribbean reef fishes at Panama. Mar. Biol. 114, 527-537. doi: 10.1007/BF00357250

Robertson, D. R., Petersen, C. W., and Brawn, J. D. (1990). Lunar reproductive cycles of benthic-brooding reef fishes: reflections of larval-biology or adult-biology? Ecol. Monogr. 60, 311-329. doi: 10.2307/1943060

Solemdal, P. (1967). The effect of salinity on buoyancy, size and development of flounder eggs. Sarsia 29, 431-442.

Steigenga, M. J. and Fischer, K. (2007). Ovarian dynamics, egg size, and egg number in relation to temperature and mating status in a butterfly. Entomol. Exp. Appl. 125, 195-203. doi: 10.1111/j.1570-7458.2007.00610.x

Thorson., G. (1950). Reproduction and larval ecology of marine bottom invertebrates. Bio. Rev. 25, 1-45. doi: 10.1111/j.1469-185X.1950.tb00585.x

Thresher, R. E. (1982). Interoceanic differences in the reproduction of coral-reef fishes. Science 218, 70-72. doi: 10.1126/science.218.4567.70

Tyler, C. R., and Sumpter, J. P. (1996). Oocyte growth and development in teleosts. Rev. Fish. Biol. Fish. 6, 287-318. doi: 10.1007/BF00122584

Vallin, L., and Nissling, A. (2000). Maternal effects on egg size and egg buoyancy of Baltic cod, Gadus morhua: Implications for stock structure effects on recruitment. Fish. Res. 49, 21-37. doi: 10.1016/S0165-7836(00)00194-6

Van Voorhies, W. A. (1996). Bergman size clines: a simple explanation for their occurrence in ectotherms. Evolution 50, 1259-1264. doi: 10.2307/2410666

Wellington, G. M., and Robertson, D. R. (2001). Variation in larval life history characteristics among reef fishes across the Isthmus of Panama. Mar. Biol. 138, 11-22. doi: 10.1007/s002270000449

Wilson, D. T., and Meekan, M. G. (2002). Growth-related advantages for survival to the point of replenishment in the coral reef fish Stegastes partitus (Pomacentridae) Mar. Ecol. Prog. Ser. 231, 247-260. doi: 10.3354/meps231247

Woods, H. A. (1999). Egg-mass size and cell size: effects of temperature on oxygen distribution. Am. Zoo. 39, 244-252.

Woods, H. A., and Hill, R. I. (2004). Temperature-dependent oxygen limitation in insect eggs. J. Exp. Biol. 207, 2267-2276. doi: 10.1242/jeb.00991

Zuo, W., Moses, M. E., West, G. B., Hou, C., and Brown, J. H. (2012). A general model of effects of temperature on ectotherm ontogenetic growth and development Proc. R. Soc. Lond. B. Biol. Sci. 279, 1840-1846. doi: $10.1098 /$ rspb.2011.2000

Conflict of Interest Statement: The authors declare that the research was conducted in the absence of any commercial or financial relationships that could be construed as a potential conflict of interest.

Received: 14 September 2014; accepted: 08 December 2014; published online: 07 January 2015.

Citation: Robertson DR and Collin $R$ (2015) Inter- and Intra-specific variation in egg size among reef fishes across the Isthmus of Panama. Front. Ecol. Evol. 2:84. doi: $10.3389 /$ fevo.2014.00084

This article was submitted to Marine Ecosystem Ecology, a section of the journal Frontiers in Ecology and Evolution.

Copyright (c) 2015 Robertson and Collin. This is an open-access article distributed under the terms of the Creative Commons Attribution License (CC BY). The use, distribution or reproduction in other forums is permitted, provided the original author(s) or licensor are credited and that the original publication in this journal is cited, in accordance with accepted academic practice. No use, distribution or reproduction is permitted which does not comply with these terms. 